\title{
PENAMBAHAN TEPUNG PRA-MASAK BUAH SUKUN (ARTOCARPUS ALTILIS) PADA PEMBUATAN SAUS TOMAT
}

\author{
Additions Of Pre-Cooked Breadfruit Flour \\ (Artocarpus Altilis) On The Making Of Tomato Sauce \\ Dewi Nur Azizah ${ }^{1}$, Ayuni Damayanti Rahayu ${ }^{2}$ \\ 1,2 Program Studi Pendidikan Teknologi Agroindustri, \\ Fakultas Pendidikan Teknologi dan Kejuruan, Universitas Pendidikan Indonesia \\ E-mail: dewinurazizah@upi.edu
}

\begin{abstract}
ABSTRAK
Saus merupakan salah satu bahan penyedap dan penambah rasa pada makanan. Saus tomat adalah produk yang dihasilkan dari campuran bubur tomat atau pasta tomat atau padatan tomat yang diperoleh dari tomat masak, yang diolah dengan bumbu-bumbu, dengan atau tanpa penambahan bahan pangan lain dan bahan tambahan pangan yang diizinkan. Beberapa jenis bumbu yang sering digunakan adalah garam, gula, cuka, bawang putih, dan rempah-rempah, seperti cengkeh dan kayu manis. Tepung pra-masak buah sukun memiliki kandungan gizi cukup tinggi dan kandungan amilopektin sebesar $77,48 \%$. Tepung pra-masak dapat membentuk larutan kental yang stabil. Oleh karena itu, tepung pra-masak buah sukun dapat dimanfaatkan sebagai bahan pengental pada saus tomat. Penelitian ini bertujuan mendapatkan konsentrasi tepung pramasak buah sukun yang tepat untuk menghasilkan saus tomat dengan karakteristik yang baik dan disukai panelis. Pada penelitian ini digunakan metode percobaan (eksperimental method) dengan menggunakan Rancangan Acak Kelompok yang diulang sebanyak tiga kali dengan empat perlakuan konsentrasi tepung pramasak buah sukun, yaitu $A=1 \%$; $=2 \% ; C=3 \%$; dan $D=4 \%$. Pengujian yang dilakukan meliputi analisis kimia, yaitu $\mathrm{pH}$ dengan menggunakan $\mathrm{pH}$ meter dan Total Padatan Terlarut (TPT) dengan menggunakan refraktometer; analisis fisik, yaitu viskositas dengan menggunakan viskometer; dan uji organoleptik dengan metode hedonik terhadap warna, aroma, tekstur, dan rasa. Hasil penelitian menunjukkan bahwa konsentrasi tepung pra-masak buah sukun sebesar $1 \%$ menghasilkan saus tomat dengan karakteristik yang baik dan disukai panelis dari segi warna, aroma, tekstur, dan rasa dengan rata-rata derajat keasaman (pH) 4,20; Total Padatan Terlarut (TPT) $16,33^{\circ}$ Brix, dan viskositas 6436,67 mPa.s.
\end{abstract}

Kata kunci : saus tomat, tepung pra-masak buah sukun, bahan pengental

\begin{abstract}
Sauce is one of the ingredients flavoring and flavor enhancers in food. Tomato sauce is a product produced from a mixture of tomato slurry or tomato paste or tomato solids obtained from cooked tomatoes, mixed with spices, with or without the addition of other foodstuffs and permissible food additives. Some of the most commonly used seasoning are salt, sugar, vinegar, garlic, and spices, such as cloves and cinnamon. Precooked breadfruit flour has a high nutrient content and amylopectin content of $77.48 \%$. Pre-cooked flour may form a stable condensed solution. Therefore, pre-cooked breadfruit flour can be utilized as thickening agent in tomato sauce. This study aims to get pre-cooked breadfruit flour concentration in appropriate to produce tomato sauce the characteristic of the good and favored by panelists. This experiment was used experimental method by using Randomized Block Design which was repeated three times with four treatment of pre-cooked breadfruit flour concentration, that is $A=1 \% ; B=2 \% ; C=3 \%$; and $D=4 \%$. Tests conducted include chemical analysis, that is $\mathrm{pH}$ by using $\mathrm{pH}$ meter and Total Dissolved Solids (TPT) by using refractometer; physical analysis, that is viscosity by using a viscometer; and organoleptic test by hedonic method to color, flavour, texture, and taste. The results showed that the concentration of pre-cooked breadfruit flour by $1 \%$ yielded tomato sauce with good characteristic and favored the panelist in terms of color, flavour, texture, and taste with average acidity $(\mathrm{pH})$ 4,20; Total Dissolved Solid (TPT) 16.33 Brix, and viscosity 6436,67 mPa.s.
\end{abstract}

Keywords : tomato sauce, pre-cooked breadfruit flour, thickening agent 


\section{PENDAHULUAN}

Sukun merupakan salah satu sumber karbohidrat yang potensial untuk dikembangkan. Produksi sukun di Indonesia terus meningkat dari 35.435 ton (tahun 2000) menjadi 92.014 ton (tahun 2007) dengan luas panen 13.359 ha (Widowati, 2009). Buah sukun mengandung karbohidrat, protein, dan lemak. Selain itu, buah sukun juga mengandung vitamin $B_{1}, B_{2}$, dan vitamin C serta mineral seperti kalsium, fosfor, dan zat besi yang dibutuhkan oleh manusia (Adinugraha, 2012). Buah sukun telah lama dimanfaatkan sebagai bahan pangan, yaitu sebagai makanan tradisional dan makanan ringan, seperti produk keripik, sukun rebus, dan tape sukun.

Buah sukun yang telah mencapai ketuaan optimal, bila tidak segera dikonsumsi atau diproses lanjut akan menjadi lunak/busuk dalam waktu beberapa hari. Untuk mengantisipasi melimpahnya sukun saat panen raya dan memperpanjang umur simpannya, maka produk setengah jadi yang sesuai adalah diproses menjadi tepung. Tepung sukun mengandung sekitar $80 \%$ karbohidrat dan energi 302 kalori/100 g. Bentuk tepung dipilih karena sebagian besar komponen zat gizi masih dapat dipertahankan, awet, mudah diformulasi dan diolah menjadi aneka ragam makanan (Widowati, 2009).

Kendala dalam pembuatan tepung sukun ialah terjadinya warna coklat saat diproses menjadi tepung. Salah satu cara proses pembuatan tepung sukun adalah dengan perlakuan pramasak. Tepung pra-masak buah sukun merupakan hasil modifikasi yang dilakukan secara fisik melalui proses pendahuluan yang berpotensi untuk dikembangkan sebagai pangan fungsional. Proses pembuatan tepung pra-masak meliputi tahap pengupasan, pembelahan, pengirisan, perebusan atau pengukusan, pendinginan, pengeringan, penggilingan, dan pengayakan (Rosida, 2013). Tepung pra-masak buah sukun pada produk pangan dapat digunakan sebagai bahan pengganti atau mensubtitusi tepung terigu atau tepung tapioka hampir sebesar $100 \%$ tergantung dari jenis produknya. Produk makanan yang telah memanfaatkan tepung pra-masak buah sukun biasanya seperti cake, mie, dan bubur sumsum (Widowati, 2001). Tepung pra-masak buah sukun memiliki kandungan amilopektin sebesar $77,48 \%$ dan amilosa sebesar 22,52\% (Agustin, 2011). Amilopektin berperan penting terhadap kelekatan atau kekentalan suatu produk, sedangkan amilosa berperan dalam kekerasan suatu produk. Oleh karena itu, tepung pra-masak buah sukun dapat diaplikasikan pada pembuatan saus tomat.

Saus tomat merupakan cairan kental (pasta) yang terbuat dari bubur tomat yang memiliki warna yang menarik dan aroma yang khas (Koswara, 2009). Pembuatan produk saus tomat sangat dipengaruhi oleh bahan yang digunakan antara lain bahan pengental. Bahan pengental yang biasa digunakan pada produk saus tomat, yaitu tepung maizena, tepung tapioka, ataupun pati termodifikasi (Setiono, 2007). Tepung pra-masak buah sukun merupakan salah satu contoh pati termodifikasi yang dapat membentuk larutan kental yang stabil. Penelitian ini bertujuan mendapatkan konsentrasi tepung pra-masak buah sukun yang tepat untuk menghasilkan saus tomat dengan karakteristik yang baik dan disukai panelis.

\section{METODE}

Metode yang digunakan pada penelitian ini, yaitu metode percobaan (eksperimental method) dengan menggunakan Rancangan Acak Kelompok yang terdiri dari empat perlakuan konsentrasi tepung pra-masak buah sukun, yaitu $A=1 \% ; B=2 \% ; C=3 \%$, dan $D=4 \%$ dengan tiga kali ulangan.

\section{HASIL DAN PEMBAHASAN \\ Karakteristik Kimia \\ Derajat Keasaman (pH)}

Berdasarkan hasil analisis ragam ternyata bahwa penambahan beberapa konsentrasi tepung pra-masak buah sukun memberikan perbedaan pengaruh yang nyata terhadap derajat keasaman $(\mathrm{pH})$ saus tomat. Hasil analisis statistik pengaruh penambahan beberapa konsentrasi tepung pra-masak buah sukun terhadap derajat keasaman $(\mathrm{pH})$ saus tomat disajikan pada Tabel 1 . 
Tabel 1. Hasil Derajat Keasaman $(\mathrm{pH})$ Saus Tomat

\begin{tabular}{ccc}
\hline Perlakuan & Rata-rata & Hasil Uji \\
\hline Konsentrasi 1\% (A) & 4,20 & a \\
Konsentrasi 2\% (B) & 4,25 & b \\
Konsentrasi 3\% (C) & 4,27 & b \\
Konsentrasi 4\% (D) & 4,31 & b \\
\hline
\end{tabular}

Keterangan : Rata-rata perlakuan yang ditandai dengan huruf yang sama tidak berbeda nyata menurut Uji Jarak Berganda Duncan pada taraf nyata $5 \%$.

Berdasarkan Tabel 1 menunjukkan bahwa perlakuan penambahan tepung pra-masak buah sukun pada konsentrasi $1 \%$ memberikan perbedaan yang nyata dibandingkan dengan perlakuan lainnya. Hal ini dikarenakan nilai $\mathrm{pH}$ menunjukkan konsentrasi ion $\mathrm{H}^{+}$yang berada dalam larutan. Makin tinggi konsentrasi tepung pra-masak buah sukun yang ditambahkan akan makin tinggi pula kemampuan tepung pra-masak buah sukun yang dapat mengikat ion $\mathrm{H}^{+}$, sehingga konsentrasi ion $\mathrm{H}^{+}$akan makin rendah. Dengan makin rendahnya ion $\mathrm{H}^{+}$yang berada dalam larutan, maka nilai $\mathrm{pH}$ akan makin rendah (Sutardi, 2001).

Nilai $\mathrm{pH}$ saus tomat yang dihasilkan berkisar antara 4,20-4,31. Nilai ini lebih tinggi dibandingkan dengan pH pada SNI saus tomat sebesar 3-4. Menurut Trisnawati (1993), pH saus adalah 3,8-4,4 dan ini sesuai dengan nilai $\mathrm{pH}$ saus tomat yang dihasilkan.

\section{Total Padatan Terlarut (TPT)}

Berdasarkan hasil analisis ragam ternyata bahwa penambahan beberapa konsentrasi tepung pra-masak buah sukun memberikan perbedaan pengaruh yang nyata terhadap Total Padatan Terlarut (TPT) saus tomat. Hasil analisis statistik pengaruh penambahan beberapa konsentrasi tepung pra-masak buah sukun terhadap Total Padatan Terlarut (TPT) saus tomat disajikan pada Tabel 2

Tabel 2. Hasil Analisis Total Padatan Terlarut (TPT) Saus Tomat

\begin{tabular}{ccc}
\hline Perlakuan & Rata-rata & Hasil Uji \\
\hline Konsentrasi 1\% (A) & $16,33^{\circ}$ Brix & a \\
Konsentrasi $\%$ (B) & $18,00^{\circ}$ Brix & b \\
Konsentrasi 3\% (C) & $19,00^{\circ}$ Brix & b \\
Konsentrasi $\%$ (D) & $20,00^{\circ}$ Brix & b \\
\hline
\end{tabular}

Keterangan : Rata-rata perlakuan yang ditandai dengan huruf yang sama tidak berbeda nyata menurut Uji Jarak Berganda Duncan pada taraf nyata $5 \%$.

Berdasarkan Tabel 2 menunjukkan bahwa perlakuan penambahan tepung pra-masak buah sukun pada konsentrasi $1 \%$ memberikan perbedaan yang nyata dibandingkan dengan perlakuan lainnya. Hal ini dikarenakan makin tinggi jumlah konsentrasi tepung pra-masak buah sukun yang ditambahkan, maka total padatan terlarut yang dihasilkan akan makin meningkat. Peningkatan TPT ini dikarenakan meningkatnya padatan terlarut yang terkandung dalam saus tomat (Meikapasa, 2016). Padatan terlarut yang terkandung dalam tomat terdiri dari gula-gula pereduksi terutama glukosa dan fruktosa dan sisanya asam-asam organik, mineral, pigmen, vitamin, dan lipid.

\section{Karakteristik Fisik Viskositas}

Berdasarkan hasil analisis ragam ternyata bahwa penambahan beberapa konsentrasi tepung pra-masak buah sukun memberikan perbedaan pengaruh yang nyata terhadap viskositas saus tomat. Hasil analisis statistik pengaruh penambahan beberapa konsentrasi tepung pra-masak buah sukun terhadap viskositas saus tomat disajikan pada Tabel 3. 
Tabel 3. Hasil Analisis Viskositas Saus Tomat

\begin{tabular}{crc}
\hline Perlakuan & \multicolumn{1}{c}{ Rata-rata } & Hasil Uji \\
\hline Konsentrasi 1\% (A) & $6436,67 \mathrm{mPa} . \mathrm{s}$ & $\mathrm{a}$ \\
Konsentrasi 2\% (B) & $9525,00 \mathrm{mPa} . \mathrm{s}$ & $\mathrm{b}$ \\
Konsentrasi 3\% (C) & $15228,33 \mathrm{mPa} . \mathrm{s}$ & $\mathrm{b}$ \\
Konsentrasi 4\% (D) & $20551,67 \mathrm{mPa} . \mathrm{s}$ & $\mathrm{b}$
\end{tabular}

Keterangan : Rata-rata perlakuan yang ditandai dengan huruf yang sama tidak berbeda nyata menurut Uji Jarak Berganda Duncan pada taraf nyata $5 \%$.

Berdasarkan Tabel 3. menunjukkan bahwa perlakuan penambahan tepung pra-masak buah sukun pada konsentrasi $1 \%$ memberikan perbedaan yang nyata dibandingkan dengan perlakuan lainnya. Hal ini dikarenakan makin tinggi jumlah konsentrasi tepung pra-masak buah sukun yang ditambahkan, maka nilai viskositas yang dihasilkan akan makin meningkat. Peningkatan viskositas ini dikarenakan membesarnya granula pati pada suhu gelatinisasi. Proses gelatinisasi pada proses pembuatan saus tomat ini dikarenakan air yang awalnya berada di luar granula dan bebas bergerak akan terperangkap masuk ke dalam butir-butir pati dan tidak akan bebas bergerak kembali. Makin banyak konsentrasi tepung yang ditambahkan, maka akan makin kental saus tomat yang dihasilkan. Seperti yang dikemukakan oleh Lusas (2001), pemanasan yang dilakukan mencapai suhu gelatinisasi, maka granula pati akan makin membesar, sehingga viskositas pasta akan meningkat.

Bila proses pemasakan terlalu lama dengan suhu yang lebih tinggi, maka saus akan menjadi padat atau tidak kental sepertinya lanyaknya saus. Cara memeriksa kekentalan, yaitu dengan cara diangkat adonan saus dengan kayu. Jika sedikit saus yang menempel tidak lagi mengalir jatuh berarti saus sudah cukup kental atau bila saus dituangkan.

\section{Sifat Organoleptik \\ Uji Kesukaan Terhadap Warna}

Warna adalah atribut kualitas yang paling penting bersama-sama dengan tekstur dan rasa. Berdasarkan hasil analisis ragam ternyata bahwa penambahan beberapa konsentrasi tepung pramasak buah sukun tidak memberikan perbedaan pengaruh yang nyata terhadap kesukaan warna saus tomat. Hasil analisis statistik pengaruh penambahan beberapa konsentrasi tepung pra-masak buah sukun terhadap kesukaan warna saus tomat disajikan pada Tabel 4.

Tabel 4. Hasil Uji Kesukaan Terhadap Warna Saus Tomat

\begin{tabular}{ccc}
\hline Perlakuan & Rata-rata & Hasil Uji \\
\hline Konsentrasi 1\% (A) & 3,27 & a \\
Konsentrasi 2\% (B) & 3,29 & a \\
Konsentrasi 3\% (C) & 3,09 & a \\
Konsentrasi 4\% (D) & 2,65 & a
\end{tabular}

Keterangan : Rata-rata perlakuan yang ditandai dengan huruf yang sama tidak berbeda nyata menurut Uji Jarak Berganda Duncan pada taraf nyata 5\%.

Pada Tabel 4 dapat dilihat bahwa nilai rata-rata kesukaan panelis terhadap warna saus tomat berkisar antara 2,65-3,29. Ini artinya bahwa warna saus tomat yang dihasilkan pada perlakuan tersebut dinilai tidak suka-suka oleh panelis. Saus tomat yang dihasilkan memiliki karakteristik warna merah oranye. Hal ini dapat terjadi akibat oksidasi pada sebagian karotenoid dalam saus tomat karena lamanya waktu pemasakan selama pengolahan. Penambahan tepung pra-masak buah sukun tidak berpengaruh terhadap warna saus tomat karena tepung pra-masak diketahui tidak merubah warna saus tomat.

Menurut Rukmana (1994), warna saus secara umum buah yang digunakan sebagai bahan 
baku dalam pembuatan saus. Warna merah oranye pada buah tomat menunjukkan adanya kandungan karoten yang berperan sebagai provitamin A, sedangkan warna merah pada buah tomat menunjukkan adanya kandungan likopen (Rukmana, 2003).

\section{Uji Kesukaan Terhadap Aroma}

Pengujian aroma dalam saus tomat dianggap penting karena dengan cepat dapat memberikan hasil penilaian terhadap produk terkait diterima atau tidaknya. Berdasarkan hasil analisis ragam ternyata bahwa penambahan beberapa konsentrasi tepung pra-masak buah sukun tidak memberikan perbedaan pengaruh yang nyata terhadap kesukaan aroma saus tomat. Hasil analisis statistik pengaruh penambahan beberapa konsentrasi tepung pra-masak buah sukun terhadap kesukaan aroma saus tomat disajikan pada Tabel 5.

Tabel 5. Hasil Uji Kesukaan Terhadap Aroma Saus Tomat

\begin{tabular}{ccc}
\hline Perlakuan & Rata-rata & Hasil Uji \\
\hline Konsentrasi 1\% (A) & 3,04 & a \\
Konsentrasi 2\% (B) & 3,20 & a \\
Konsentrasi 3\% (C) & 3,25 & a \\
Konsentrasi 4\% (D) & 3,18 & a \\
\hline
\end{tabular}

Keterangan : Rata-rata perlakuan yang ditandai dengan huruf yang sama tidak berbeda nyata menurut Uji Jarak Berganda Duncan pada taraf nyata $5 \%$.

Pada Tabel 5 dapat dilihat bahwa nilai rata-rata kesukaan panelis terhadap aroma saus tomat berkisar antara 3,04-3,25. Ini artinya bahwa aroma saus tomat yang dihasilkan pada perlakuan tersebut dinilai biasa-suka oleh panelis.Saus tomat yang dihasilkan memiliki karakteristik aroma yang tidak terlalu tercium pekat. Adanya aroma dikarenakan tomat memiliki senyawa volatil, seperti karbonil, alkohol, ester, lakton, asetat, ketal, dan sulfur. Penambahan tepung pra-masak buah sukun tidak berpengaruh terhadap aroma saus tomat karena tepung pra-masak diketahui tidak berbau khas (tidak beraroma).

Aroma saus tomat dihasilkan dari bahan yang bersifat volatil, seperti bawang putih, cengkeh, kayu manis, dan lada. Masing-masing bahan ini mempunyai fungsi bagi produk saus tomat. Bawang putih menimbulkan aroma yang tajam. Cengkeh dan kayu manis ditambahkan untuk memperkaya aroma, sedangkan lada menambah aroma (Hambali, dkk, 2006).

\section{Uji Kesukaan Terhadap Tekstur}

Tekstur merupakan sifat bahan atau produk yang dapat dirasakan melalui sentuhan kulit ataupun indera pengecap.

\section{Uji Kesukaan Terhadap Tekstur Indera Peraba}

Pada penelitian ini, indera peraba yang digunakan adalah dua jari tangan, yaitu jari jempol dan telunjuk. Berdasarkan hasil analisis ragam ternyata bahwa penambahan beberapa konsentrasi tepung pra-masak buah sukun tidak memberikan perbedaan pengaruh yang nyata terhadap kesukaan tekstur indera peraba saus tomat. Hasil analisis statistik pengaruh penambahan beberapa konsentrasi tepung pra-masak buah sukun terhadap kesukaan tekstur indera peraba saus tomat disajikan pada Tabel 6.

Tabel 6. Hasil Uji Kesukaan Terhadap Tekstur Indera Peraba Saus Tomat

\begin{tabular}{ccc}
\hline Perlakuan & Rata-rata & Hasil Uji \\
\hline Konsentrasi 1\% (A) & 2,98 & a \\
Konsentrasi 2\% (B) & 3,18 & $a$ \\
Konsentrasi 3\% (C) & 3,13 & $a$ \\
Konsentrasi 4\% (D) & 2,86 & a \\
\hline
\end{tabular}

Keterangan : Rata-rata perlakuan yang ditandai dengan huruf yang sama tidak berbeda nyata menurut Uji Jarak Berganda Duncan pada taraf nyata 5\%. 
Pada Tabel 6 dapat dilihat bahwa nilai rata-rata kesukaan panelis terhadap tekstur saus tomat berkisar antara 2,86-3,18. Ini artinya bahwa tekstur saus tomat yang dihasilkan pada perlakuan tersebut dinilai tidak suka-suka oleh panelis. Saus tomat yang dihasilkan memiliki karakteristik tekstur yang tidak terlalu kental. Kekentalan saus tomat diakibatkan oleh kandungan pati yang terdapat pada tepung pra-masak buah sukun.

\section{Uji Kesukaan Terhadap Tekstur Indera Pengecap}

Penentuan tekstur dengan indera pengecap yang digunakan pada penelitian ini yaitu dengan merasakan tekstur saus tomat saat dirasakan di dalam mulut. Berdasarkan hasil analisis ragam ternyata bahwa penambahan beberapa konsentrasi tepung pra-masak buah sukun memberikan perbedaan pengaruh yang nyata terhadap kesukaan tekstur indera pengecap saus tomat. Hasil analisis statistik pengaruh penambahan beberapa konsentrasi tepung pra-masak buah sukun terhadap kesukaan tekstur indera pengecap saus tomat disajikan pada Tabel 7 .

Pada Tabel 7 dapat dilihat bahwa nilai rata-rata kesukaan panelis terhadap tekstur saus tomat berkisar antara 2,47-3,35. Ini artinya bahwa tekstur saus tomat yang dihasilkan pada perlakuan tersebut dinilai tidak suka-suka oleh panelis. Saus tomat yang dihasilkan memiliki karakteristik tekstur yang tidak terlalu kental. Kekentalan saus tomat diakibatkan oleh kandungan pati yang terdapat pada tepung pra-masak buah sukun.

Tabel 7. Hasil Uji Kesukaan Terhadap Tekstur Indera Pengecap Saus Tomat

\begin{tabular}{ccc}
\hline Perlakuan & Rata-rata & Hasil Uji \\
\hline Konsentrasi 1\% (A) & 3,35 & $\mathrm{~b}$ \\
Konsentrasi 2\% (B) & 2,91 & $\mathrm{a}$ \\
Konsentrasi 3\% (C) & 2,73 & $\mathrm{a}$ \\
Konsentrasi 4\% (D) & 2,47 & $\mathrm{a}$ \\
\hline
\end{tabular}

Keterangan : Rata-rata perlakuan yang ditandai dengan huruf yang sama tidak berbeda nyata menurut Uji Jarak Berganda Duncan pada taraf nyata $5 \%$.

Pada Tabel 7 dapat dilihat bahwa nilai rata-rata kesukaan panelis terhadap tekstur saus tomat berkisar antara 2,47-3,35. Ini artinya bahwa tekstur saus tomat yang dihasilkan pada perlakuan tersebut dinilai tidak suka-suka oleh panelis. Saus tomat yang dihasilkan memiliki karakteristik tekstur yang tidak terlalu kental. Kekentalan saus tomat diakibatkan oleh kandungan pati yang terdapat pada tepung pra-masak buah sukun.

\section{Uji Kesukaan Terhadap Rasa}

Rasa berperan sebagai rangsangan yang ditimbulkan oleh bahan yang dimakan, yang dirasakan oleh indera pengecap, dan rangsangan lainnya seperti penerimaan derajat panas oleh mulut (Mann, 2000). Berdasarkan hasil analisis ragam ternyata bahwa penambahan beberapa konsentrasi tepung pra-masak buah sukun tidak memberikan perbedaan pengaruh yang nyata terhadap kesukaan rasa saus tomat. Analisis statistik pengaruh penambahan beberapa konsentrasi tepung pra-masak sukun terhadap kesukaan rasa saus tomat tersaji pada Tabel 8.

Tabel 8. Hasil Uji Kesukaan Terhadap Rasa Saus Tomat

\begin{tabular}{ccc}
\hline Perlakuan & Rata-rata & Hasil Uji \\
\hline Konsentrasi 1\% (A) & 2,93 & a \\
Konsentrasi 2\% (B) & 2,71 & a \\
Konsentrasi 3\% (C) & 2,69 & a \\
Konsentrasi 4\% (D) & 2,60 & a \\
\hline
\end{tabular}

Keterangan : Rata-rata perlakuan yang ditandai dengan huruf yang sama tidak berbeda nyata menurut Uji Jarak Berganda Duncan pada taraf nyata $5 \%$. 
Pada Tabel 8 dapat dilihat bahwa nilai rata-rata kesukaan panelis terhadap rasa saus tomat berkisar antara 2,60-2,93. Ini artinya bahwa rasa saus tomat yang dihasilkan pada perlakuan tersebut dinilai tidak suka-biasa oleh panelis. Saus tomat yang dihasilkan memiliki karakteristik rasa yang tidak terlalu manis dan asam.

Rasa saus tomat dihasilkan dari bahan lain, seperti gula pasir, garam, dan cuka. Masingmasing bahan ini mempunyai fungsi bagi produk saus tomat. Gula pasir selain sebagai pemanis atau penyedap, juga berfungsi mempertahankan kadar air dan menjadikan produk lebih awet. Garam digunakan sebagai penyedap atau memberi rasa gurih, asin, dan menjadikan produk lebih awet. Cuka berfungsi sebagai penyedap atau pemberi rasa asam dan sebagai penghambat pertumbuhan mikroorganisme, sehingga produk lebih awet (Hambali, dkk, 2006).

\section{KESIMPULAN}

1. Penambahan beberapa konsentrasi tepung pra-masak buah sukun memberikan perbedaan pengaruh yang nyata terhadap derajat keasaman $(\mathrm{pH})$, Total Padatan Terlarut (TPT), viskositas, dan tingkat kesukaan terhadap tekstur indera pengecap, tetapi tidak berpengaruh terhadap sifat yang lainnya, yaitu tingkat kesukaan terhadap warna, aroma, tekstur indera peraba, dan rasa. .

2. Konsentrasi tepung pra-masak buah sukun sebesar $1 \%$ menghasilkan saus tomat dengan karakteristik yang baik dan disukai panelis dari segi warna, aroma, tekstur, dan rasa dengan rata-rata derajat keasaman $(\mathrm{pH}) 4,20$; Total Padatan Terlarut (TPT) $16,33^{\circ}$ Brix, dan viskositas 6436,67 mPa.s.

\section{DAFTAR PUSTAKA}

Adinugraha, H. A. (2012). “Variasi Morfologi dan Kandungan Gizi Buah Sukun”. Wana Benih. 13 (2) : 99-106.

Agustin, S. (2011). Kajian Pengaruh Hidrokoloid dan $\mathrm{CaCl}_{2}$ Terhadap Profil Gelatinisasi Bahan Baku Serta Aplikasinya Pada Bihun Sukun. Sekolah Pasca Sarjana. Institut Pertanian Bogor.

Djafar, T. F. dan Rahayu, S. (2005). Pemanfaatan Sukun Sebagai Bahan Pangan Alternatif. Jurnal Agros 6 (2) 133-141.

Hambali, E., A. Suryani, dan M. Insanur. (2006). Membuat Saus Cabai dan Tomat. Jakarta : Penebar Swadaya.

Koswara, S. (2009). Pengolahan Aneka Saus. EbookPangan.com

Lusas, R. W. dan L. W. Rooney. (2001). Snack Food Processing. CRC Press, Boca Raton, FL.

Mann, de. J. M. (2000). Kimia Makanan. Penerjemah Kosasih Padmawinata. Bandung : ITB.

Meikapasa, N. W. P. (2016). Karakteristik Total Padatan Terlarut (TPT), Stabilitas likopen dan Vitamin C Saus Tomat Pada Berbagai Kombinasi Suhu dan Waktu Pemasakan. Ganec Swara. 10. (1).

Rosida, dan Ratna Y. (2013). Pengaruh Proses Pengolahan Terhadap Kadar Pati Resisten Sukun (Artocarpus Altilis Park). Jawa Timur : Program Studi Teknologi Pangan, FTI, UPN Veteran

Rukmana, R. (2003). Tomat dan Cherry. Yogyakarta : Kanisius.

Setiono. (2007). Pengental Saos Tomat. Surabaya : Universitas Katolik Widya Mandala.

Widowati S. N., dkk. (2001). Studi Potensi dan Peningkatan Daya Guna Sumber Pangan Lokal Untuk Penganeragaman Pangan di Sulawesi Selatan. Laporan Hasil Penelitian. Bogor : Puslitbangtan.

Widowati S. (2001). Prospek Sukun (Artocarpus communis) sebagai Pangan Sumber Karbohidrat dalam Mendukung Diversifikasi Konsumsi Pangan. Jurnal Pangan Edisi No.56/XVIII/Oktober-Desember/2009. 